\title{
MAPPING CONDITION BAHAN AJAR DAN LKS PENDIDIKAN JASMANI DI PONDOK PESANTREN DKI JAKARTA
}

\author{
Tomi Ari Sudewo \\ Guru SDN Cipete Utara 11 Pagi Jakarta \\ Email: andikurniawan62@gmail.com
}

\begin{abstract}
The purpose of the study was to gain an in-depth understanding, especially towards the implementation of teaching materials and physical education worksheets at Islamic Boarding Schools in DKI Jakarta. The approach in this study uses a qualitative approach by using descriptive methods. The study population was the Islamic Boarding School educational institutions in the five regions of DKI Jakarta Province, namely Al Wathoniyah Islamic Boarding School, Al Itqon, Al Hamid, Al Jauhariyah, Al Qalam, An-Nur, An Nuriyah, As Shiddiqiyah, Darunnajah, Miftahul Ulum, Persis 69, PTDI Al Qesmaniyah, Al Hidayah, Ash-Syawarifiyah Malacca. The research sample was obtained through purposive sample technique. Data sources in this study were teachers and principals related to the Implementation of Physical Education in Islamic boarding schools in DKI Jakarta. Analysis of research data using descriptive statistics. The results of the study indicate that the assessment component/evaluation of teaching materials and worksheets; these two components are opportunities for Islamic Boarding Schools, but in reality they are not well-developed so that they cause enough problems for the implementation of physical education in Islamic Boarding Schools in DKI Jakarta.
\end{abstract}

Keywords: Teaching material assessment, LKS assessment, Physical education, Islamic boarding school, DKI Jakarta

\begin{abstract}
Abstrak
Tujuan penelitian adalah untuk memperoleh pemahaman yang mendalam khususnya terhadap pelaksanaan bahan ajar dan LKS pendidikan jasmani di Pondok Pesantren di DKI Jakarta. Pendekatan dalam penelitian ini menggunakan pendekatan kualitatif dengan dengan menggunakan metode deskriptif. Populasi penelitian adalah lembaga pendidikan Pondok Pesantren yang berada di lima wilayah Provinsi DKI Jakarta yaitu Pondok Pesantren Al Wathoniyah, Al Itqon, Al Hamid, Al Jauhariyah, Al Qalam, An Nur, An Nuriyah, As Shiddiqiyah, Darunnajah, Miftahul Ulum, Persis 69, PTDI Al Qesmaniyah, Al Hidayah, Asy-Syawarifiyah Malaka. Sampel penelitian diperoleh melalui teknik sampel bertujuan (purposive sample). Sumber data dalam penelitian ini adalah guru dan kepala sekolah terkait Pelaksanaan Pendidikan Jasmani di pondok pesantren di DKI Jakarta. Analisis data penelitian menggunakan statistik deskriptif. Hasil penelitian menunjukkan bahwa komponen assessment / penilaian bahan ajar dan LKS; dua komponen ini merupakan peluang bagi ponpes, tetapi pada kenyataannya kurang dikembangkan, sehingga cukup mendatangkan masalah bagi pelaksanaan pendidikan jasmani di Pondok Pesantren di DKI Jakarta.
\end{abstract}

Kata kunci : Assessment bahan ajar, assessment LKS, Pendidikan jasmani, Pondok Pesantren, DKI Jakarta

\section{PENDAHULUAN}

Dalam kurikulum pendidikan

nasional, salah satu kegiatan pendidikan

yang harus dilaksanakan adalah program pendidikan jasmani dan kesehatan

(Penjaskes) sebagaimana tertuang dalam

bab IX pasal 39 butir $3 \mathrm{k}$, yaitu tentang

isi kurikulum bahan kajian pendidikan 
jasmani dan kesehatan merupakan salah satu wahana untuk mencapai tujuan pendidikan dalam keseluruhan komponen sistem pendidikan nasional. Penjaskes sebagai salah satu subsistem pendidikan yang wajib diajarkan di sekolah memiliki peran penting yang sangat sentral dalam pembentukan manusia Indonesia seutuhnya.

Sehubungan dengan itu, pendidikan jasmani harus memiliki tujuan yang sejalan dengan tujuan pendidikan nasional yaitu memberi kontribusi yang sangat berharga dan memberi inspirasi bagi kesejahteraan hidup manusia. Makna yang terkandung dalam pendidikan jasmani tidak sekedar pendidikan yang bersifat physical atau aktivitas fisik tetapi lebih luas lagi keterkaitannya dengan tujuan pendidikan secara menyeluruh serta memberikan kontribusi kehidupan individu.

Secara konseptual pendidikan jasmani memiliki peran penting dalam peningkatan kualitas hidup peserta didik. Pendidikan jasmani diartikan sebagai pendidikan melalui dan dari pendidikan jasmani, Siendentop mengatakan sebagai "education through and of physical activities" Pendidikan jasmani modern yang lebih menekankan pada pendidikan melalui aktivitas jasmani didasarkan pada anggapan bahwa jiwa dan raga merupakan satu kesatuan yang tidak bisa dipisah-pisahkan. Pandangan ini memandang kehidupan sebagai totalitas. Wall dan Murray (dalam Dini Rosdiani, 2013:140), mengemukakan hal serupa dari sudut pandang yang lebih spesifik (istimewa; menurut jenisnya), "masa anak-anak adalah masa yang sangat kompleks, dimana pikiran, perasaan, dan tindakannya selalu berubah-ubah seperti halnya sifat anak-anak yang selalu dinamis pada saat mereka tumbuh dan berkembang, maka perubahan satu elemen sering kali mempengaruhi perubahan pada eleman lainnya. Oleh karena itulah,anak secara keseluruhan yang harus kita didik, tidak hanya mendidik jasmani atau tubuhnya saja.

Pendidikan jasmani merupakan bagian integral dari keseluruhan proses pendidikan. Artinya, pendidikan jasmani menjadi salah satu media untuk membantu tercapai tujuan pendidikan secara keseluruhan, proses pendidikan jasmani diharapkan dapat berkontribusi positif terhadap peningkatan indeks pembangunan manusia (human index development). Permainan, rekreasi, ketangkasan, olahraga dan aktivitasaktivitas fisik lainnya, merupakan 
materi-materi yang terkandung dalam pendidikan jasmani karena diakui mengandung nilai-nilai pendidikan yang hakiki.

Berdasarkan uraian tersebut, bahwa pendidikan jasmani yang pada dasarnya merupakan media untuk meraih tujuan pendidikan sekaligus juga untuk meraih tujuan yang bersifat internal kedalam aktivitas fisik itu sendiri. Melalui pendidikan jasmani, diharapkan dalam jangka waktu pendek para siswa agar memiliki kebugaran jasmani, kesenangan melakukan aktivitas fisik dan olahraga (gaya hidup yang aktif dan sehat), memiliki prestasi olahraga yang sesuai dengan tahapannya, dan memperoleh nilai-nilai pendidikan yang diperlukan bagi anak itu untuk bekal kehidupan sekarang maupun dimasa yang akan datang. Namun, Dalam Pelaksanaannya pengajaran pendidikan jasmani berjalan belum efektif seperti yang diharapkan, fakta dilapangan masih menunjukan bahwa pendidikan jasmani memiliki setumpuk permasalahan, terutama yang terkait dengan kualitas proses pembelajaran, seperti dijelaskan Ring bahwa masalah pendidikan jasmani terletak pada level pedagogis. Selama ini proses pembelajaran yang mekanistis dan reduksionistik. Pembelajaran pendidikan Jasmani cenderung tradisional.

Guru lebih banyak berperan sebagai perekayasa tingkah laku siswa, proses pembelajaran lebih berpusat pada guru, perilaku siswa dibentuk melalui atmosfir pembelajaran yang sistematis dan kaku, dan siswa lebih banyak dituntut untuk menyelesaikan semua aktivitasnya dengan lingkungan belajar yang ada. Dengan begitu siswa menjadi pasif, seluruh perilakunya diarahkan oleh guru dalam lingkungannya yang terbatas, isi pelajaran lebih ditekankan pada aspek fisik dan penguasaan kecabangan olahraga. Konsep dasar pendidikan jasmani dan model pengajaran pendidikan jasmani yang efektif perlu dipahami oleh mereka yang hendak mengajar pendidikan jasmani.

Model pembelajaran pendidikan jasmani tidak harus berpusat pada guru tetapi berpusat pada siswa. Orientasi pembelajaran harus disesuaikan dengan perkembangan anak, isi dan urusan materi serta cara penyampaian harus disesuaikan sehingga menarik dan menyenangkan, sasaran pembelajaran ditujukan bukan hanya mengembangkan ketrampilan olahraga semata, tetapi pada perkembangan pribadi anak seutuhnya. 
Cholik Mutohir menyatakan bahwa tidak ada pendidikan yang lengkap tanpa pendidikan jasmani, dan tidak ada pendidikan jasmani tanpa media gerak, karena gerak sebagai aktivitas jasmani merupakan dasar alami bagi manusia untuk belajar mengenal dunia dan dirinya sendiri. Pendidikan jasmani pada hakikatnya adalah proses pendidikan yang memanfaatkan aktivitas fisik untuk menghasilkan perubahan holistik dalam kualitas individu, baik dalam hal fisik, mental, serta emosional. Pendidikan jasmani memperlakukan anak sebagai sebuah kesatuan utuh, mahluk total, daripada hanya menganggapnya sebagai seseorang yang terpisah kualitas fisik dan mentalnya. Pada kenyataannya, pendidikan jasmani adalah suatu bidang kajian yang sungguh luas. Titik perhatiannya adalah peningkatan gerak insani sesuai dengan karakteristik anak. Lebih khusus lagi, penjas berkaitan dengan hubungan antara gerak manusia dan wilayah pendidikan lainnya hubungan dari perkembangan tubuh-fisik dengan pikiran dan jiwanya.

Pendidikan jasmani merupakan bagian dari pendidikan keseluruhan yang dalam pembelajarannya mengutamakan aktivitas jasmani dan pembinaan serta kebiasaan hidup sehat menuju pada pertumbuhan dan perkembangan jasmani, mental, sosial dan emosional. Perubahan perilaku peserta didik yang sesuai dengan harapan akan terjadi melalui keterlibatan mereka dalam program pendidikan jasmani. Program ini berisi seperangkat pengalaman belajar yang direncanakan dan dikelola oleh para pendidik guna mencapai tujuan yang bersifat majemuk. Dan sebagai bagian integral dari proses pendidikan keseluruhan, pendidikan jasmani merupakan usaha untuk meningkatkan kondisi fisik para siswa, agar mereka mampu mengikuti aktivitas pembelajaran dengan baik yang diberikan di sekolah sesuai dengan kurikulum yang telah ditetapkan (Abdul Kadir Ateng, 1992:1). Dapat disimpulkan bahwa pendidikan jasmani merupakan proses pendidikan yang memanfaatkan aktivitas jasmani dan direncanakan secara sistematik bertujuan untuk meningkatkan individu secara organik, neoromoskuler, perseptual, kognitif, sosial dan emosional.

Pondok pesantren merupakan sistem pendidikan yang berusaha mengintegrasikan secara penuh sistem tradisional dan sistem sekolah formal (seperti madrasah). Pesantren sekarang 
ini dapat dibedakan kepada dua macam, yaitu pesantren tradisional dan pesantren modern. Sistem pendidikan pesantren tradisional sering disebut sistem salafi yaitu sistem yang tetap mempertahankan pengajaran kitab-kitab Islam klasik sebagai inti pendidikan di pesantren.

Tujuan proses modernisasi pondok pesantren adalah berusaha untuk menyempurnakan sistem pendidikan Islam yang ada di pesantren. Akhir-akhir ini pondok pesantren mempunyai kecenderungan-kecenderungan baru dalam rangka renovasi terhadap sistem yang selama ini dipergunakan. Perubahan-perubahan yang bisa dilihat di pesantren modern antara lain: 1) mulai akrab dengan metodologi ilmiah modern, 2) lebih terbuka atas perkembangan di luar dirinya, 3) diversifikasi program dan kegiatan di pesantren makin terbuka dan luas, dan 4) sudah dapat berfungsi sebagai pusat pengembangan masyarakat (Hasbullah, 1999:155).

Sekarang ini di Indonesia, ada ribuan lembaga pendidikan Islam terletak di seluruh nusantara. Lembaga pendidikan ini memliki sebutan/nama yang cukup beragam, seperti dayah dan rangkang di Aceh, surau di Sumatra Barat, dan pondok pesantren di Jawa. Pondok pesantren di Jawa itu membentuk banyak macam-macam jenis. Perbedaan jenis-jenis pondok pesantren di Jawa dapat dilihat dari segi ilmu yang diajarkan, jumlah santri, pola kepemimpinan atau perkembangan ilmu teknologi.

Pendidikan jasmani di pondok pesantren meskipun telah diakui perannya dalam pengembangan kualitas SDM yang sempurna oleh pakar pendidikan di manapun berada, termasuk di Indonesia. Namun dalam kenyataan di lapangan, pelajaran penjas di pondok pesantren belum mampu berbuat banyak dalam ikut menciptakan peserta didik yang handal dari segi fisik maupun nonfisik. Fenomena ini terjadi karena dipengaruhi oleh banyak faktor yang saling terkait, diantaranya: kebijakan pemerintah mengenai kurikulum penjas di Pondok Pesantren maupun disekolah umum yang harus diberlakukan tidak sepadan dengan tujuan yang akan dicapai. Hal ini ditandai oleh:1) Perubahan nama bidang, namun tidak diikuti isi program yang harus diajarkan, 2) tidak diperhitungkan dalam menentukan kenaikan kelas, 3) pengurangan jam pelajaran pada pesantren hanya dijadikan sebagai bidang studi pilihan, 4) penilaian hasil belajar tidak melibatkan aspek kognitif, 
5) tidak tersedianya sarana dan prasarana yang memadai, dan 6) kurangnya dukungan yang positif dari pihak-pihak yang terkait, misalnya kepsek, guru bidang studi lain, dan orang tua siswa.

Selama ini proses pembelajaran yang mekanistis dan reduksionistik. Pembelajaran pendidikan Jasmani cenderung tradisional. Guru lebih banyak berperan sebagai perekayasa tingkah laku siswa, proses pembelajaran lebih berpusat pada guru, perilaku siswa dibentuk melalui atmosfir pembelajaran yang sistematis dan kaku, dan siswa lebih banyak dituntut untuk menyelesaikan semua aktivitasnya dengan lingkungan belajar yang ada. Dengan begitu siswa menjadi pasif, seluruh perilakunya diarahkan oleh guru dalam lingkungannya yang terbatas, isi pelajaran lebih ditekankan pada aspek fisik dan penguasaan kecabangan olahraga. namun sungguhpun demikian penulis melihat antusias dan semangat yang tinggi tetap diperlihatkan para siswa/santri dalam melaksanakan Pelajaran Pendidikan Jasmani.

Pelajaran Pendidikan Jasmani dalam pelaksanaannnya diajarkan diseluruh Pesantren yang ada di DKI Jakarta (tentunya dengan modifikasi dan aturan masing-masing Pondok
Pesantren) yang berjumlah 119 Pondok Pesantren yang tersebar di lima wilayah kota meliputi: Jakarta Timur, Jakarta Selatan, Jakarta Pusat, Jakarta Barat, Jakarta Utara yang didalamnya termasuk kepulauan Seribu. Yang menarik dalam temuan awal peneliti menemukan; dalam hal pengajarannya gurunya merupakan santri yang dianggap "jago" dalam olahraga tertentu atau santri yang memiliki tubuh yang atletis, Dalam pelaksanaan pengajaran penjas ada yang masuk kedalam struktur kurikulum dimasukan kedalam mata pelajaran dan terjadwalkan seperti mata pelajaran lainnya atau ada yang dijadikan extra kurikuler atau jadwal tersendiri pada hari minggu, fasilitas pembelajarannya dalam hal ini lapangan lebih banyak menyatu dengan tempat parkir atau diadakan diluar sekolah, untuk kelengkapan peralatan seperti bola sepak, volley atau futsal terlihat seadanya. namun sungguhpun demikian penulis melihat antusias dan semangat yang tinggi tetap diperlihatkan para siswa/santri dalam melaksanakan Pelajaran Pendidikan Jasmani. Berdasarkan hal itu, maka peneliti tertarik untuk memahami lebih mendalam tentang Pelaksanaan Pendidikan Jasmani di Pondok Pesantren di DKI Jakarta. 
Terminology pondok pesantren berasal dari kata santri yang berarti seseorang yang belajar agama Islam, kata santri tersebut kemudian mendapat awalan "pe" dan akhiran"an" yang berarti tempat tinggal santri. Dengan demikian pesantren mempunyai arti tempat orang berkumpul untuk belajar agama Islam. Ada juga yang mengartikan pesantren adalah suatu lembaga pendidikan Islam Indonesia yang bersifat "tradisional" untuk mendalami ilmu tentang agama Islam dan mengamalkan sebagai pedoman hidup keseharian. Secara terminologi dapat dikemukakan disini beberapa pandangan yang mengarah kepada definisi Pondok Pesantren. Abdurahman Wahid (2001:17) mendefinisikan pesantren secara teknis, Pondok Pesantren adalah tempat dimana santri tinggal.

Nurcholis Majid Pondok Pesantren atau asal kata dari "santri" digambarkan menjadi dua pengertian yaitu, Pertama bahwa "santri" itu berasal dari perkataan "Sastri", sebuah kata dari saskerta, yang artinya melek huruf. karena kira-kira pada permulaan tumbuhnya kekuasaan politik islam di Demak, Kaum santri adalah kelas “Literary” bagi orang Jawa. Ini disebabkan pengetahuan mereka tentang agama melalui kitab-kitab bertulisan dan berbahasa Arab. Dari sini bisa kita asumsikan bahwa menjadi santri berarti juga menjadimengerti agama (melalui kitab-kitab tersebut). Kedua, santri berasal dari bahasa Jawa, persisnya dari kata "cantrik", yang artinya seseorang yang selalu mengikuti seorang guru kemana guru ini pergi menetap. Tentunya dengan tujuan dapat belajar darinya mengenai suatu keahlian. Pola hubungan "guru-cantrik" itu kemudian diteruskan dalam masa islam. Pada proses selanjutnya "guru-Cantrik" menjadi "guru-santri". Karena guru di pakai secara luas, yang mengandung secara luas, untuk guru yang terkemuka kemudian digunakan kata Kyai, yang mengandung arti tua atau sacral, keramat, dan sakti.Pada perkembangan selanjutnya, dikenal istilah Kyai-santri.

Secara definitive Imam Zarkasyi (pendiri pondok modern Darussalam gontor) Sebagai lembaga pendidikan islam dengan sistem asrama ataau pondok, dimana kyai sebagai pigur sentralnya, masjid sebagai pusat yang menjiwainya, dan pengajaran agama islam dibawah bimbingan kyai yang diikuti santri sebagai kegiatan utamanya (Amir Hamzah Winosukarto, et.al, 1996: 56). 
Menurut M. Arifin (1991:240) pondok pesantren adalah suatu lembaga pendidikan agama Islam yang tumbuh serta diakui masyarakat sekitar dengan sistem asrama. Para santri menerima pendidikan agama melalui sistem pengajian atau madrasah yang sepenuhnya berada di bawah kedaulatan kepemimipinan seorang atau beberapa orang kiai. Kemudian Lembaga Research Islam (1975:52) mendefinisikan pondok pesantren adalah suatu tempat yang tersedia untuk para santri dalam menerima pelajaran-pelajaran agama Islam sekaligus tempat berkumpul dan tempat tinggal para santri tersebut. Oleh Mujammil Qomar (2005:2), menyatakan bahwa pondok pesantren memiliki persepsi yang plural. Pondok pesantren dapat dipandang sebagai lembaga ritual, lembaga pembinaan moral, lembaga dakwah, dan yang paling populer adalah sebagai institusi pendidikan Islam yang mengalami proses romantika kehidupan dalam menghadapi berbagai tantangan internal maupun eksternal.

Dan menurut tradisi umum pondok pesantren, pengetahuan seseorang diukur dari jumlah buku yang telah dipelajarinya dan kepada 'ulama' siapa seseorang telah berguru. Jumlah buku dalam tulisan Arab yang ditulis oleh para 'ulama' terkenal yang harus dibaca telah ditentukan oleh lembaga pondok pesantren. Kemudian kyai dari berbagai pondok pesantren mengembangkan diri untuk memiliki keahlian dalam cabang pengetahuan tertentu, kitab-kitab yang mereka baca pun cukup terkenal.

Dengan demikian homogenitas pandangan hidup keagamaan terbina dengan baik, tetapi disamping itu sifat kekhususan seorang kiai juga dapat tersalurkan. Pondok pesantren Tremas di Pacitan misalnya, terkenal dengan kiaikiai yang ahli dalam tata bahasa Arab; K.H Hasyim Asyari dari Tebu ireng terkenal dalam ilmu hadits, sedangkan Pondok pesantren Jampes di Kediri terkenal dengan kiai-kiai yang ahli dalam bidang tasawuf. Kemasyhuran seorang kiai dan jumlah maupun mutu kitab-kitab yang diajarkan sebuah pondok pesantren menjadi salah satu faktor pembeda antara satu pondok pesantren dengan pondok pesantren lain. Pesantren tumbuh dari bawah, atas kehendak masyarakat yang terdiri atas : kiai, santri, dan masyarakat sekitar, termasuk perangkat desa. Di antara mereka, kiai memiliki peran paling dominan dalam memuwujudkan dan 
mengembangkan sebuah pondok pesantren. Sehingga, pondok pesantren merupakan lembaga pendidikan Islam paling otonom yang tidak bisa diintervensi pihak-pihak luar kecuali atas izin kiai. Adapun perbedaan variasi bentuk pendidikan pondok pesantren ini diakibatkan perbedaan kondisi sosial kultural masyarakat yang mengelilinginya. Dari berbagai uraian di atas dapat ditarik kesimpulan bahwa Pondok Pesantren sebagai laboratorium kehidupan tempat para santri belajar hidup dan bermasyarakat dalam segi dan aspeknya. Oleh karenanya, kajian terkait penilaian/assessment bahan ajar dan LKS Pendidikan Jasmani di Pondok Pesantren ini sangat penting dilakukan guna meningkatkan pemahaman yang mendalam terhadap pelaksanaan pendidikan jasmani di Pondok Pesantren di DKI Jakarta.

\section{METODOLOGI PENELITIAN}

Tujuan penelitian adalah untuk memperoleh pemahaman yang mendalam khususnya terhadap pelaksanaan bahan ajar dan LKS pendidikan jasmani di Pondok Pesantren di DKI Jakarta. Pendekatan dalam penelitian ini menggunakan pendekatan kualitatif dengan dengan menggunakan metode deskriptif. Populasi penelitian adalah lembaga pendidikan Pondok Pesantren yang berada di lima wilayah Provinsi DKI Jakarta yaitu Pondok Pesantren Al Wathoniyah, Al Itqon, Al Hamid, Al Jauhariyah, Al Qalam, An Nur, An Nuriyah, As Shiddiqiyah, Darunnajah, Miftahul Ulum, Persis 69, PTDI Al Qesmaniyah, Al Hidayah, AsySyawarifiyah Malaka. Sampel penelitian diperoleh melalui teknik sampel bertujuan (purposive sample). Sumber data dalam penelitian ini adalah guru dan kepala sekolah terkait Pelaksanaan Pendidikan Jasmani di pondok pesantren di DKI Jakarta. Analisis data penelitian menggunakan statistik deskriptif.

\section{HASIL DAN PEMBAHASAN}

\section{a. Penilaian / Assessment Bahan Ajar}

\section{1) Orisinalitas Materi Ajar}

Berdasarkan hasil penelitian mengenai orisinalitas materi ajar menurut Kepala Sekolah Pondok Pesantren di Jakarta, terdapat $71 \%$ responden dengan 10 responden yang memilih skor baik dalam instrumen penilaian tersebut, $29 \%$ responden yang memilih skor sangat baik orisinalitas materi ajar. Hal tersebut menunjukkan bahwa kepala sekolah di pondok pesantren dapat menilai 
Jurnal Parameter Volume 31 No. 1

DOI : doi.org/10.21009/parameter.311.04

P-ISSN : 0216-261X E-ISSN : 2620-9519

Bahan Ajar terhadap Pendidikan Jasmani dalam orisinalitas materi ajar di Pondok Pesantren, sudah sangat baik dalam penerapannya menurut Kepala Sekolah Pondok Pesantren di Jakarta.

\section{2) Akurasi Materi Ajar}

Berdasarkan hasil penelitian akurasi materi ajar menurut Kepala Sekolah Pondok Pesantren di Jakarta, terdapat $43 \%$ responden dengan 6 responden yang memilih skor baik akurasi materi ajar tersebut, $21 \%$ responden yang memilih skor sangat baik, dan $36 \%$ responden yang memilih kurang baik akurasi materi ajar. Hal tersebut menunjukkan bahwa kepala sekolah di pondok pesantren dapat menilai Bahan Ajar terhadap Pendidikan Jasmani dalam akurasi materi ajar di Pondok Pesantren, sudah baik dalam penerapannya menurut Kepala Sekolah Pondok Pesantren di Jakarta.

\section{3) Kesesuaian materi ajar}

Berdasarkan hasil penelitian mengenai kesesuaian materi ajar menurut Kepala Sekolah Pondok Pesantren di Jakarta, terdapat 14\% responden dengan 2 responden yang memilih skor sangat baik dalam kesesuaian materi ajar, dan $43 \%$ responden memilih skor baik demikian pula dalam skor kurang baik, $43 \%$ responden pula memilih kesesuaian materi ajar. Hal tersebut menunjukkan bahwa kepala sekolah di pondok pesantren dapat menilai penilaian terhadap Bahan Ajar terhadap Pendidikan Jasmani dalam kesesuaian materi ajar di Pondok Pesantren, namun kurang baik sampai dengan baik dalam penerapannya menurut Kepala Sekolah Pondok Pesantren di Jakarta.

\section{4) Relevan dan Kompeten}

Berdasarkan hasil penelitian mengenai relevan dan kompeten menurut Kepala Sekolah Pondok Pesantren di Jakarta, terdapat 64\% responden dengan 9 responden yang memilih skor baik dalam relevan dan kompeten tersebut, $36 \%$ responden yang memilih skor sangat baik relevan dan kompeten. Hal tersebut menunjukkan bahwa kepala sekolah di pondok pesantren dapat menilai Bahan Ajar terhadap Pendidikan Jasmani dalam relevan dan kompeten di Pondok Pesantren, sudah baik dalam penerapannya menurut Kepala Sekolah Pondok Pesantren di Jakarta. 


\section{5) Keluasan Konten Bahan Ajar}

Berdasarkan hasil penelitian mengenai keluasan konten bahan ajar menurut Kepala Sekolah Pondok Pesantren di Jakarta, terdapat $72 \%$ responden dengan 10 responden yang memilih skor baik dalam keluasan konten bahan ajar tersebut, 29\% responden yang memilih skor sangat baik keluasan konten bahan ajar. Hal tersebut menunjukkan bahwa kepala sekolah di pondok pesantren dapat menilai Bahan Ajar terhadap Pendidikan Jasmani dalam keluasan konten bahan ajar di Pondok Pesantren, sudah baik dalam penerapannya menurut Kepala Sekolah Pondok Pesantren di Jakarta.

\section{6) Kedalaman Konten Bahan} Ajar

Berdasarkan hasil penelitian mengenai kedalaman konten bahan ajar menurut Kepala Sekolah Pondok Pesantren di Jakarta, terdapat 14\% responden dengan 2 responden yang memilih skor sangat baik dalam kedalaman konten bahan ajar, dan $43 \%$ responden memilih skor baik demikian pula dalam skor kurang baik, $43 \%$ responden memilih kedalaman konten bahan ajar. Hal tersebut menunjukkan bahwa kepala sekolah di pondok pesantren dapat menilai penilaian terhadap Bahan Ajar terhadap Pendidikan Jasmani dalam kedalaman konten bahan ajar di Pondok Pesantren, namun kurang baik sampai dengan baik dalam penerapannya menurut Kepala Sekolah Pondok Pesantren di Jakarta.

7) Sumber Bahan Ajar Bernuansa Indonesia

Berdasarkan hasil penelitian mengenai sumber bahan ajar bernuansa Indonesia menurut Kepala Sekolah Pondok Pesantren di Jakarta, terdapat $79 \%$ responden dengan 11 responden yang memilih skor baik dalam sumber bahan ajar bernuansa Indonesia tersebut, $21 \%$ responden yang memilih skor sangat baik sumber bahan ajar bernuansa Indonesia. Hal tersebut menunjukkan bahwa kepala sekolah di pondok pesantren dapat menilai Bahan Ajar terhadap Pendidikan Jasmani dalam sumber bahan ajar bernuansa Indonesia di Pondok Pesantren, sudah baik dalam penerapannya menurut Kepala Sekolah Pondok Pesantren di Jakarta.

\section{8) Dapat dipahami}

Berdasarkan hasil penelitian mengenai dapat dipahami bahan ajar 
menurut Kepala Sekolah Pondok Pesantren di Jakarta, terdapat $72 \%$ responden dengan 10 responden yang memilih skor baik dalam dapat dipahami bahan ajar tersebut, 29\% responden yang memilih skor sangat baik dapat dipahami bahan ajar. Hal tersebut menunjukkan bahwa kepala sekolah di pondok pesantren dapat menilai Bahan Ajar terhadap Pendidikan Jasmani dalam dapat dipahami bahan ajar di Pondok Pesantren, sudah baik dalam penerapannya menurut Kepala Sekolah Pondok Pesantren di Jakarta.

\section{9) Materi dapat Diulang}

Berdasarkan hasil penelitian mengenai materi dapat diulang menurut Kepala Sekolah Pondok Pesantren di Jakarta, terdapat 14\% responden dengan 2 responden yang memilih skor sangat baik dalam materi dapat diulang, dan $43 \%$ responden memilih skor baik demikian pula dalam skor kurang baik, $43 \%$ responden memilih materi dapat diulang. Hal tersebut menunjukkan bahwa kepala sekolah di pondok pesantren dapat menilai penilaian terhadap Bahan Ajar terhadap Pendidikan Jasmani dalam materi dapat diulang di Pondok
Pesantren, namun kurang baik sampai dengan baik dalam penerapannya menurut Kepala Sekolah Pondok Pesantren di Jakarta.

\section{0) Sesuai Alokasi Waktu}

Berdasarkan hasil penelitian mengenai sesuai alokasi waktu menurut Kepala Sekolah Pondok Pesantren di Jakarta, terdapat 79\% responden dengan 11 responden yang memilih skor baik dalam sesuai alokasi waktu tersebut, 21\% responden yang memilih skor sangat baik sesuai alokasi waktu. Hal tersebut menunjukkan bahwa kepala sekolah di pondok pesantren dapat menilai Bahan Ajar terhadap Pendidikan Jasmani dalam sesuai alokasi waktu di Pondok Pesantren, sudah baik dalam penerapannya menurut Kepala Sekolah Pondok Pesantren di Jakarta.

b. Penilaian/Assessment

Lembar Kerja Siswa

\section{1) Memenuhi Persyaratan}

Berdasarkan hasil penelitian mengenai memenuhi persyaratan menurut Kepala Sekolah Pondok Pesantren di Jakarta, terdapat $72 \%$ responden dengan 10 responden yang memilih skor baik dalam memenuhi persyaratan tersebut, $29 \%$ responden 
Jurnal Parameter Volume 31 No. 1

DOI : doi.org/10.21009/parameter.311.04

P-ISSN : 0216-261X E-ISSN : 2620-9519

yang memilih skor sangat baik memenuhi persyaratan. Hal tersebut menunjukkan bahwa kepala sekolah di pondok pesantren dapat menilai Lembar Kerja Siswa terhadap Pendidikan Jasmani dalam memenuhi persyaratan di Pondok Pesantren, sudah baik dalam penerapannya menurut Kepala Sekolah Pondok Pesantren di Jakarta.

\section{2) Mempermudah Pelaksanaan Pembelajaran}

Berdasarkan hasil penelitian mempermudah pelaksanaan pembelajaran menurut Kepala Sekolah Pondok Pesantren di Jakarta, terdapat $43 \%$ responden dengan 6 responden yang memilih skor baik mempermudah pelaksanaan pembelajaran tersebut, $21 \%$ responden yang memilih skor sangat baik, dan $36 \%$ responden yang memilih mempermudah pelaksanaan pembelajaran. Hal tersebut menunjukkan bahwa kepala sekolah di pondok pesantren dapat Lembar Kerja Siswa terhadap Pendidikan Jasmani dalam mempermudah pelaksanaan pembelajaran di Pondok Pesantren, sudah baik dalam penerapannya menurut Kepala Sekolah Pondok Pesantren di Jakarta.
3) Mengembangkan

Konsep

\section{Pembelajaran}

Berdasarkan hasil penelitian mengenai mengembangkan konsep pembelajaran menurut Kepala Sekolah Pondok Pesantren di Jakarta, terdapat $14 \%$ responden dengan 2 responden yang memilih skor sangat baik dalam materi dapat diulang, dan $43 \%$ responden memilih skor baik demikian pula dalam skor kurang baik, $43 \%$ responden memilih mengembangkan konsep pembelajaran. Hal tersebut menunjukkan bahwa kepala sekolah di pondok pesantren dapat menilai penilaian terhadap Lembar Kerja Siswa terhadap Pendidikan Jasmani dalam mengembangkan konsep pembelajaran di Pondok Pesantren, namun kurang baik sampai dengan baik dalam penerapannya menurut Kepala Sekolah Pondok Pesantren di Jakarta.

\section{4) Adanya Judul, Mata Pelajaran,} Semester, dan Satuan

Berdasarkan hasil penelitian mengenai judul, mata pelajaran, semester, dan satuan menurut Kepala Sekolah Pondok Pesantren di Jakarta, terdapat $64 \%$ responden dengan 9 responden yang memilih skor baik 
judul, mata pelajaran, semester, dan satuan tersebut, $36 \%$ responden yang memilih skor sangat baik judul, mata pelajaran, semester, dan satuan. Hal tersebut menunjukkan bahwa kepala sekolah di pondok pesantren dapat menilai Lembar Kerja Siswa terhadap Pendidikan Jasmani dalam judul, mata pelajaran, semester, dansatuan di Pondok Pesantren, sudah baik dalam penerapannya menurut Kepala Sekolah Pondok Pesantren di Jakarta.

\section{5) Adanya SK, KD, dan Indikator Pencapaian Kompetensi}

Berdasarkan hasil penelitian mengenai adanya $\mathrm{SK}, \mathrm{KD}$, dan indikator pencapaian kompetensi menurut Kepala Sekolah Pondok Pesantren di Jakarta, terdapat $72 \%$ responden dengan 10 responden yang memilih skor baik dalam adanya sk, $\mathrm{kd}$, dan indikator pencapaian kompetensi tersebut, $29 \%$ responden yang memilih skor sangat baik adanya sk, kd, dan indikator pencapaian kompetensi. Hal tersebut menunjukkan bahwa kepala sekolah di pondok pesantren dapat menilai Lembar Kerja Siswa terhadap Pendidikan Jasmani dalam adanya sk, kd, dan indikator pencapaian kompetensi di Pondok Pesantren, sudah baik dalam penerapannya menurut Kepala Sekolah Pondok Pesantren di Jakarta.

\section{6) Adanya tujuan pembelajaran di LKS}

Berdasarkan hasil penelitian mengenai tujuan pembelajaran menurut Kepala Sekolah Pondok Pesantren di Jakarta, terdapat 14\% responden dengan 2 responden yang memilih skor sangat baik dalam tujuan pembelajaran, dan $43 \%$ responden memilih skor baik demikian pula dalam skor kurang baik, $43 \%$ responden memilih tujuan pembelajaran. Hal tersebut menunjukkan bahwa kepala sekolah di pondok pesantren dapat menilai penilaian terhadap Lembar Kerja Siswa terhadap Pendidikan Jasmani dalam tujuan pembelajaran di Pondok Pesantren, namun kurang baik sampai dengan baik dalam penerapannya menurut Kepala Sekolah Pondok Pesantren di Jakarta.

\section{7) Adanya petunjuk belajar}

Berdasarkan hasil penelitian mengenai adanya petunjuk belajar di LKS menurut Kepala Sekolah Pondok Pesantren di Jakarta, terdapat 79\% responden dengan 11 responden yang 
Jurnal Parameter Volume 31 No. 1

DOI : doi.org/10.21009/parameter.311.04

P-ISSN : 0216-261X E-ISSN : 2620-9519

memilih skor baik dalam adanya petunjuk belajar di LKS tersebut, $21 \%$ responden yang memilih skor sangat baik adanya petunjuk belajar di LKS. Hal tersebut menunjukkan bahwa kepala sekolah di pondok pesantren dapat menilai Lembar Kerja Siswa terhadap Pendidikan Jasmani dalam adanya petunjuk belajar di LKS di Pondok Pesantren, sudah baik dalam penerapannya menurut Kepala Sekolah Pondok Pesantren di Jakarta.

\section{8) Adanya informasi pendukung}

Berdasarkan hasil penelitian mengenai adanya informasi pendukung di LKS menurut Kepala Sekolah Pondok Pesantren di Jakarta, terdapat $71 \%$ responden dengan 10 responden yang memilih skor baik dalam adanya informasi pendukung di LKS tersebut, 29\% responden yang memilih skor sangat baik adanya informasi pendukung di LKS. Hal tersebut menunjukkan bahwa kepala sekolah di pondok pesantren dapat menilai Lembar Kerja Siswa terhadap Pendidikan Jasmani dalam adanya informasi pendukung di Pondok Pesantren, sudah baik dalam penerapannya menurut Kepala Sekolah Pondok Pesantren di Jakarta.

\section{9) Adanya Rangkaian Kegiatan Pembelajaran}

Berdasarkan hasil penelitian mengenai adanya rangkaian kegiatan pembelajaran menurut Kepala Sekolah Pondok Pesantren di Jakarta, terdapat 14\% responden dengan 2 responden yang memilih skor sangat baik dalam adanya rangkaian kegiatan pembelajaran, dan $43 \%$ responden memilih skor baik demikian pula dalam skor kurang baik, $43 \%$ responden memilih adanya rangkaian kegiatan pembelajaran. Hal tersebut menunjukkan bahwa kepala sekolah di pondok pesantren dapat menilai penilaian terhadap Lembar Kerja Siswa terhadap Pendidikan Jasmani dalam adanya rangkaian kegiatan pembelajaran di Pondok Pesantren, namun kurang baik sampai dengan baik dalam penerapannya menurut Kepala Sekolah Pondok Pesantren di Jakarta.

\section{0) Adanya Rangkaian Kegiatan Pembelajaran}

Berdasarkan hasil penelitian mengenai adanya rangkaian kegiatan pembelajaran di LKS menurut Kepala Sekolah Pondok Pesantren di Jakarta, terdapat 43\% 
Jurnal Parameter Volume 31 No. 1

DOI : doi.org/10.21009/parameter.311.04

P-ISSN : 0216-261X E-ISSN : 2620-9519

responden dengan 6 responden yang memilih skor kurang baik dalam adanya rangkaian kegiatan pembelajaran di LKS, dan 29\% responden memilih skor baik demikian pula dalam skor sangat baik, 29\% responden pula memilih adanya rangkaian kegiatan pembelajaran di LKS. Hal tersebut menunjukkan bahwa kepala sekolah di pondok pesantren dapat menilai penilaian terhadap Lembar Kerja SIswa terhadap Pendidikan Jasmani dalam adanya rangkaian kegiatan pembelajaran di LKS di Pondok Pesantren, namun kurang baik penerapannya menurut Kepala Sekolah Pondok Pesantren di Jakarta.

\section{c. Mapping Condition Bahan Ajar dan} LKS Pendidikan Jasmani

Permasalahan Penilaian Bahan Ajar dalam Kajian Pelaksanaan Pendidikan Jasmani di Pondok Pesantren lebih fokus mengenai Materi atau isi merupakan karya orisinal. Materi atau isi memiliki kebenaran keilmuan, sesuai dengan perkembangan ilmu yang mutakhir, sahih, dan akurat, Mengacu pada materi pokok pembelajaran, Relevan dengan kompetensi dan tujuan pembelajaran yang akan dicapai, Keluasan konten bahan ajar, Kedalaman konten bahan ajar, Memaksimalkan penggunaan sumbersumber yang sesuai dengan kondisi Indonesia, Dapat dipahami dari yang mudah ke yg sulit, dari yang kongkret untuk memahami yg abstrak, Materi dapat diulang untuk memperkuat pemahaman, dan Sesuai dengan alokasi waktu.

Bahan ajar yang terdapat dalam pelaksaan pendidikan jasmani di Pondok Pesantren sudah sesuai dengan aturan dari pemerintah, dimana terdapat Orisinalitas materi ajar, Akurasi materi ajar, Kesesuaian materi ajar, Relevan dan kompeten, Keluasan konten bahan ajar, Sesuai alokasi waktu dan Dapat dipahami. Dan Kepala Sekolah dapat menyampaikan dan memberi arahan kepada guru Pendidikan Jasmani, dan memiliki ketercapaian dalam praktikumnya.

Penilaian Lembar Kerja Siswa (LKS) meliputi Memenuhi persyaratan secara didaktik, konstruksi, dan teknis, Membantu dan mempermudah pelaksanaan 
Jurnal Parameter Volume 31 No. 1

DOI : doi.org/10.21009/parameter.311.04

P-ISSN : 0216-261X E-ISSN : 2620-9519 pembelajaran, Mengembangkan konsep, Adanya judul, mata pelajaran, semester, dan satuan pendidikan, Tertuliskan SK, KD, dan indikator pencapaian kompetensi, Tertuliskan tujuan pembelajaran, Tertuliskan petunjuk belajar, Tertuliskan informasi pendukung (uraian singkat materi pembelajaran), Tertuliskan rangkaian kegiatan atau tugas-tugas dan langkah-langkah kerja (setiap langkah ada perintah atau petunjuk kerja dan ruang atau tempat untuk menjawab atau mengerjakan tugas atau kerja), dan Adanya penilaian (terkait dengan kegiatan atau tugas-tugas atau kerja).

Lembar Kerja Siswa dalam pelaksaan Pendidikan Jasmani di Pondok Pesantren DKI Jakarta tidak berjalan dengan baik, dimana seluruh Pondok Pesantren di DKI Jakarta tidak memiliki LKS yang diberikan ke anak didik, hal tersebut dikarenakan pendidiknya tidak memiliki pemahaman mengenai Pendidikan Jasmani, dimana menurut mereka Pendidikan Jasmani merupakan kegiatan dilapangan dan merupakan kegiatan yang konteksional. Menurut Sistem Pendidikan Nasional UU No. 20 tahun 2003, dimana perangkat pembelajaran komponen LKS harus dibuat dan dikembangkan. Selama ini pelaksaan Pendidikan Jasmani hanya bersifat aktivitas fisik.

\section{PENUTUP}

Hasil penelitian menunjukkan bahwa komponen assessment / penilaian bahan ajar dan LKS; dua komponen ini merupakan peluang bagi Pondok Pesantren (ponpes), tetapi pada kenyataannya kurang dikembangkan, sehingga cukup mendatangkan masalah bagi pelaksanaan pendidikan jasmani di Pondok Pesantren di DKI Jakarta.

\section{DAFTAR PUSTAKA}

Abdul Kadir Ateng. 1992. Azas dan Landasan Pendidikan Jasmani. Jakarta : Dirjen dikti Proyek Pembinaan Tenaga Kependidikan, h. 1

Abdurahman $\quad$ Wahid. Menggerakan Tradisi:essai pesantren. Yogyakarta: LKIS, h.17 
Jurnal Parameter Volume 31 No. 1

DOI : doi.org/10.21009/parameter.311.04

P-ISSN : 0216-261X E-ISSN : 2620-9519

Amir Hamzah Winosukarto, et.al, Imam

Zarkasyi. 1996. Dari Gontor

Merintis Pesantren Modern.

Ponorogo: Gontor press, cet ke

1.h,56

Dini Rosdiani. 2013. Perencanaan Pembelajaran dalam Penjas dan Kesehatan. Bandung: Alfabeta, h. 140

Hasbullah. 1999. Sejarah Pendidikan Islam di Indonesia:Lintasan Sejarah Pertumbuhan dan Perkembangan. PT Raja Grafindo Persada, Jakarta, h. 155

Lembaga Research Islam (Pondok Pesantren Luhur). 1975. Sejarah dan Dakwah Islamiyah Sunan Giri, Gresik. H.52
M. Arifin. $2005 . \quad$ Kapita SelektaPendidikan( Islam dan Umum. Jakarta: Bumi Aksara, h. 240

Mujamil Qomar. 2005. Pesantren dari Transformasi metodologi mеnuju demokrasi intitusi. Jakarta, Erlangga, h.2

Tim Pengembang KBK Pendidikan Jasmani Menengah Kejuruan. 2003. Kurikulum berbasis kompetensi untuk sekolah menengah kejuruan (SMK)Mata Pelajaran: Pendidikan Jasmani. Jakarta: Direktorat Pendidikan Menengah Kejuruan, Direktorat Jenderal Pendidikan Dasar dan Menengah, dan Departemen Pendidikan Nasional 